\title{
Faktor-faktor yang Mempengaruhi Optimalisasi Unit Rawat Jalan di RS X
}

\section{Factors Influencing the Optimization of Outpatient Unit in X Hospital}

\author{
Kurnia Widyaningrum, Tatong Harijanto, Hartojo \\ Program Studi Magister Manajemen Rumah Sakit Fakultas Kedokteran Universitas Brawijaya Malang
}

\begin{abstract}
ABSTRAK
Utilisasi pelayanan rawat jalan merupakan salah satu indikator penting kinerja rumah sakit. Hasil studi pendahuluan di unit rawat jalan RS tempat studi menunjukkan nilai utilitas dan optimalisasi masih belum maksimal dan terjadi penurunan angka kepuasan pasien. Tujuan dari penelitian ini adalah untuk mencari faktor-faktor yang mempengaruhi optimalisasi unit rawat jalan dan solusi untuk meningkatkan optimalisasinya. Metode yang digunakan adalah dengan observasi, telaah dokumen dan wawancara. Hasil penelitian menunjukkan bahwa terdapat gap antara utilitas ruang dan optimalisasi petugas. Utilitas ruang hanya $22,4 \%$ sedangkan optimalisasi masing-masing dokter sudah sangat optimal yaitu $141,6 \%$, $172,9 \%$ dan $68,75 \%$. Dengan menggunakan diagram fishbone ditemukan faktor-faktor utama kurang optimalnya unit rawat jalan adalah dari sumberdaya manusia yang kurang dan lingkungan yang kurang nyaman. Analisis 5 why's menemukan sistem monitoring dan evaluasi (monev) belum berjalan secara maksimal sebagai akar masalah. Solusi yang disepakati untuk meningkatkan optimalisasi di unit rawat jalan ini adalah dengan mengaktifkan kembali tim monev dengan pemberian pelatihan tentang monev.
\end{abstract}

Kata Kunci: Evaluasi kinerja rawat jalan, monitoring, optimalisasi, utilisasi

\section{ABSTRACT}

Outpatient service utilization is one of the important indicators of hospital performance. The preliminary study result in a selected hospital outpatient unit showed that optimization and utilization were not maximized and a decline in the patient satisfaction occurred. The purpose of this study is to find the factors influencing the optimization of outpatient units and solutions to improve the optimization. The methods used in this study were observation, document review, and interview. The results show that there is a gap between the room utility and personnel optimization. The utility of room is only $22,4 \%$, while each doctor optimization is highly optimized namely 141,6\%, 172,9\%, and 68,75\%. By using fishbone diagrams, the main factors of non-optimal outpatient unit are from the lack of human resources and the uncomfortable environment. 5 whys analysis finds monitoring system and evaluation have not run optimally. Solutions agreed to improve the optimization in outpatient unit are to reactivate the monitoring and evaluation team and the provision of training on monitoring and evaluation.

Keywords: Evaluation, human resources, monitoring, optimization, utilization

Jurnal Kedokteran Brawijaya, Vol. 28, Suplemen No. 2, 2015; Korespondensi: Kurnia Widyaningrum. Program Studi Magister Manajemen Rumah Sakit Fakultas Kedokteran Universitas Brawijaya Malang, Jl. Veteran Malang 65145 Tel. (0341) 569117 Email: kurnia_widyaningrum@yahoo.com 


\section{PENDAHULUAN}

Pelayanan kesehatan adalah pelayanan jasa yang dapat dinilai atau dirasakan melalui sebuah kinerja (performance). Pelanggan akan meyimpulkan kualitas jasa dari tempat (place), orang (people), peralatan (equipment), bahan-bahan komunikasi (communication materials), simbol, harga yang mereka amati (1). Rumah sakit merupakan penyelenggara pelayanan kesehatan yang memberikan pelayanan yang menyeluruh. Hakikat dasar dari penyelenggaraan pelayanan kesehatan di rumah sakit adalah pemenuhan kebutuhan pasien terkait dengan penyelesaian masalah kesehatan. Oleh karena itu pasien memandang bahwa rumah sakit harus mampu dalam memberikan pelayanan medik yang berkualitas, cepat tanggap atas keluhan serta penyediaan pelayanan kesehatan yang nyaman.

Di sisi lain rumah sakit perlu melakukan suatu upaya untuk berkembang. Salah satunya adalah dengan meningkatkan pendapatan dari pasien baik secara langsung (out of pocket) maupun secara tidak langsung melalui asuransi kesehatan. Oleh sebab itu rumah sakit perlu mempertahankan dan meningkatkan kunjungan pasien dengan menampilkan dan memberikan pelayanan kesehatan yang berkualitas. Kuncinya adalah memenuhi atau melebihi harapan pasien tentang mutu pelayanan yang diterimanya. Setelah menerima jasa pelayanan kesehatan, pasien akan membandingkan jasa yang dialami dengan dengan jasa yang diharapkan. Jika jasa yang dirasakan tidak sesuai dengan jasa yang diharapkan, maka pasien tidak puas dan akhirnya tidak akan loyal kepada rumah sakit (2).

Kepuasan pelanggan berhubungan dengan loyalitas pelanggan, menurut Kotler dan Keller salah satu kunci untuk mempertahankan pelanggan adalah kepuasan pelanggan (3). Hal senada disampaikan Hafizurrahman bahwa hubungan antara kepuasan pasien dan kunjungan berpola positif, yaitu semakin meningkat kepuasan maka tingkat kunjungan juga meningkat (4). Meskipun menurut Singh, kepuasan pelanggan tidak selalu dapat menjamin loyalitas pelanggan. Pada beberapa industri penyedia layanan jasa $75 \%$ pelanggan yang berpindah pada penyedia layanan lain menyatakan puas ataupun sangat puas terhadap penyedia layanan sebelumnya (5). Dengan berorientasi pada kualitas, rumah sakit akan mampu mendapatkan profitabilitas jangka panjang yang diperoleh dari kepuasan pasien.

Pelayanan rawat jalan merupakan salah satu pelayanan yang menjadi perhatian utama rumah sakit seluruh dunia, karena jumlah pasien rawat jalan yang jauh lebih besar dari pasien rawat inap sehingga pasien rawat jalan merupakan sumber pangsa pasar yang besar yang diprediksikan akan mengimbangi pemasukan dari pasien rawat inap di masa mendatang yang dapat meningkatkan finansial rumah sakit. Selain itu di dalam memilih rumah sakit untuk rawat inap, pilihan pasien biasanya dimulai dari pelayanan rawat jalan.

Data kinerja rawat jalan pada rumah sakit tempat studi menunjukkan kunjungan rawat jalan spesialis terjadi peningkatan sejak tahun 2011 dengan rerata peningkatan $1,17 \%$. Meskipun terjadi peningkatan namun peningkatan tersebut belum mencapai target peningkatan pendapatan. Pencapaian pendapatan rawat jalan masih kurang $17 \%$ dari target pendapatan. Peningkatan jumlah kunjungan pasien rawat jalan sebagian besar adalah pasien baru yang berasal dari pasien Badan Penyelenggara Jaminan Sosial (BPJS) Kesehatan. Fakta ini perlu dicermati mengingat sampai saat ini rumah sakit yang melayani BPJS belum banyak di kota Malang. Ketika semua rumah sakit sudah ikut berpartisipasi sebagai provider BPJS, maka setiap pasien berhak memilih rumah sakit rujukan sehingga meningkatkan kompetisi. Bahkan penelitian terdahulu menyatakan ada perbedaan presepsi kepuasan pasien asuransi yang lebih rendah daripada pasien umum, sehingga rumah sakit harus berupaya untuk menarik kunjungan (6).

Permasalahan kinerja lain yang ditemukan adalah kepuasan dan kecepatan pelayanan. Faktor kepuasan dan kecepatan pelayanan rawat jalan masih belum memenuhi standar minimal rumah sakit di unit rawat jalan. Berdasarkan hasil survei kepuasan pasien tahun 2012 dan 2013 dapat digambarkan bahwa pelayanan rawat jalan di RS tempat studi sudah cukup baik. Meskipun demikian terdapat penurunan angka kepuasan pasien pada kecepatan respon petugas, keramahan petugas, pelayanan dokter, dan kenyamanan ruang tunggu. Kecepatan pelayanan juga menjadi keluhan utama atau saran yang banyak diberikan pelanggan pada survei tahun 2012 dan 2013. Kecepatan pelayanan yang dikeluhkan diantaranya adalah waktu pendaftaran, waktu pelayanan dokter (ketepatan waktu pelayanan). Keluhan tersebut didukung data kecepatan pelayanan rawat jalan yang belum mencapai standar (>60 menit). Hal ini sejalan dengan penelitian terdahulu yang dilakukan oleh Suharmiati dan Didik Budijanto (2007) yang menyatakan bahwa kepuasan pasien sangat dipengaruhi oleh faktor lamanya waktu tunggu dan faktor environment (7). Data tersebut menunjukkan masih belum optimalnya kinerja rawat jalan sebagai salah satu unit utama dari sisi kunjungan dan pendapatan bagi rumah sakit. Penelitian ini dilakukan untuk mengkaji faktor yang mempengaruhi optimalisasi kinerja rawat jalan.

\section{METODE}

Penelitian ini dilakukan dengan metode desktriptif kualitatif. Pengambilan data diawali dengan melakukan observasi kegiatan di unit rawat jalan, wawancara dan telaah dokumen observasi dilakukan selama kurang lebih 3 minggu sejak tanggal 6 Oktober 2014 sampai tanggal 25 Oktober 2014. Observasi yang dilakukan adalah tentang SDM yaitu ketenagaan di unit rawat jalan, tentang environment yaitu jumlah ruang yang digunakan, kondisi ruang tunggu dan pelayanan. Pengamatan juga dilakukan untuk mengetahui waktu kunjungan pasien, alur pasien, sistem dan tata cara pelayanan pasien. Pengamatan dilakukan 2 sampai 3 kali dalam seminggu, pada shift pagi atau sore. Dari pengamatan tersebut kemudian dihitung utilitas ruang dan optimalisasi ruang. Tujuan dari menghitung utilitas dirawat jalan adalah untuk menghitung prosentase penggunaan ruangan poliklinik, dokter dan jam prakteknya sehingga peneliti bisa mengetahui apakah ruangan sudah digunakan semaksimal mungkin atau belum. Pengukuran optimalisasi ruang bertujuan untuk mengetahui apakah layanan yang diberikan sudah optimal dengan membandingkan jumlah jam praktek dengan jumlah pasien.

Nilai guna (utility) adalah kemampuan suatu barang atau jasa untuk memberikan kepuasan pada manusia dalam mencukupi kebutuhan manusia (8). Utilitas pelayanan yang diukur dalam penelitian ini adalah utilitas ruang, 
optimalisasi ruang, dan optimalisasi dokter. Utilitas ruang diperhitungkan dari prosentase jam praktek terhadap ruangan, jam efektif, dan hari kerja. Optimalisasi ruang diperhitungkan dari jumlah pasien terhadap ruangan, jam efektif, optimalisasi, dan hari kerja. Optimalisasi dokter diperhitungkan dari jumlah pasien terhadap jam praktek dan faktor optimalisasi.

Data sekunder didapatkan dengan melakukan telaah dokumen. Dokumen yang dikaji meliputi jumlah karyawan, jumlah kunjungan di unit rawat jalan, jenis penyakit dengan melihat 10 penyakit terbanyak, dan asal pembiayaan pasien. Selain mencari dan mengetahui nilai utilitas dan optimalisasi ruang, juga dilakukan wawancara terstruktur kepada 1 orang dokter penanggung jawab rawat jalan, 1 orang kepala perawat unit rawat jalan, 4 orang perawat unit rawat jalan, 2 orang bagian pendaftaran, dan 2 orang satuan pengaman untuk menggali lebih dalam dan mencari penyebab faktor-faktor yang mempengaruhi optimalisasi di unit rawat jalan. Dalam wawancara diberikan pertanyaan yang sama yaitu pendapat staf tentang penyebab penurunan kepuasan pasien, komplain pasien dan kurang optimalnya pelayanan di unit rawat jalan serta saran tentang solusi terhadap penyebab permasalahan. Dilakukan brainstorming dengan staf dan manajemen di unit rawat jalan dan disusun analisis akar masalah secara holistik dalam bentuk diagram fish-bone Ishikawa kemudian dilanjutkan metode 5 why's sehingga ditemukan permasalahan utama.

\section{HASIL}

\section{Utilisasi Pelayanan Rawat Jalan Anak}

Disamping pengukuran utilitas penelitian juga mengamati proses pelayanan. Hasil observasi menunjukkan waktu peak kunjungan pasien yaitu pada jam 9 pagi sampai jam 1 siang dan jam 7 malam sampai jam 9 malam dan tidak semua ruangan digunakan secara full time. Ruang tunggu nampak kurang nyaman terutama saat peak kunjungan pasien karena kapasitas ruang dan jumlah pengunjung yang tidak proporsional. Meskipun sudah terdapat alur pasien dan petunjuk ruang pemeriksaan tetapi gambaran alur masih kurang komunikatif sehingga masih banyak pasien merasa tidak jelas dan kebingungan. Di unit rawat jalan juga ditemukan ada beberapa tempat yang jumlah petugasnya kurang sehingga menyebabkan pelayanan tampak kurang maksimal, misalkan pada resepsionis yang juga bertugas sebagai pendaftaran dan perawat sebagai asisten dokter. Pengamatan juga mengidentifikasi beberapa dokter yang datang tidak sesuai dengan jam praktek atau pergi keluar kota hingga beberapa hari tanpa dokter pengganti sehingga pasien yang sudah datang kecewa karena tidak mendapatkan layanan.

Hasil juga menunjukkan bahwa penggunaan ruang masih sangat rendah. Penghitungan utilisasi ruang didasarkan atas penggunaan suatu ruangan dengan jumlah jam praktek. Penggunaan ruang dianggap baik bila mencapai angka $80 \%$. sedangkan yang dicapai baru $22,4 \%$ yang menunjukkan penggunaan ruang belum optimal. Optimalisasi dihitung dengan membandingkan jumlah pasien yang diterima dengan kapasitas ruang dengan hasil 5,75\%. Disisi lain optimalisasi masing-masing dokter justru menunjukkan berapa dokter bekerja melebihi kapasitasnya.
Tabel 1. Gambaran utilitas di klinik rawat jalan anak

\begin{tabular}{cll}
\hline No. & \multicolumn{1}{c}{ Indikator } & \multicolumn{1}{c}{ Utilitas } \\
\hline 1 & Utilitas ruang & $22,4 \%$ \\
2 & Optimalisasi ruang & $5,75 \%$ \\
3 & Optimalisasi dokter & dr. A $=141,6 \%$ \\
& & dr. B $=172,9 \%$ \\
& & dr. C $=68,75 \%$ \\
\hline
\end{tabular}

Faktor-faktor yang Mempengaruhi Utilitas Rawat Jalan Anak

Hasil analisis dengan fishbone pada faktor Man ditemukan faktor-faktor yang mempengaruhi rawat jalan adalah faktor SDM yang kurang memadai. SDM yang dimaksud salah satunya adalah tenaga pendaftar dan resepsionis yang masih menjadi satu. Hal ini menjadi masalah ketika pasien datang secara bersamaan maka petugas layanan pendaftaran tidak bisa melakukan tugas sebagai resepsionis secara bersamaan. Kondisi tersebut bisa menyebabkan pasien kemungkinan salah alur dan tidak segera mendapatkan informasi yang benar dan jelas. Petugas untuk asisten dokter spesialis juga kurang. Berdasarkan cara penghitungan direktorat pelayanan keperawatan Dirjen Yanmed Depkes RI jumlah perawat yang dibutuhkan di unit rawat jalan ini sebanyak 8 orang, sedangkan saat ini baru terpenuhi 4 orang.

Faktor Man yang lain adalah kurangnya pengetahuan dari tenaga perawat dan resepsionis yang ada tentang berkomunikasi yang baik. Selain itu layanan yang belum optimal juga dipengaruhi karena tenaga dokter yang datang tidak sesuai dengan jam praktek, tenaga dokter yang mengganti jam praktek secara mendadak dan banyaknya jadwal poli spesialistik yang masih kosong. Faktor machine sangat dipengaruhi oleh kelengkapan alatalat komunikasi dan sarana yang terkait dengan fungsi pelayanan. Hasil dari wawancara didapatkan bahwa mesin komputer sudah memadai, yang masih kurang adalah mesin pencetak (printer) untuk mencetak SEP (surat eligibilitas peserta) dan karcis. Form SEP butuh dicetak setiap ada kunjungan pasien BPJS sebagai bukti bahwa peserta tertanggung. Pada faktor methode yang ditemui adalah masalah alur yang kurang komunikatif sehingga pasien belum mendapatkan informasi secara jelas dari alur tersebut. Sosialisasi tentang persyaratan kelengkapan administrasi peserta asuransi juga masih belum maksimal sehingga potensi terjadi ketidakpuasan dari pasien. Faktor material yang ditemukan adalah kondisi pasien datang tidak membawa kelengkapan berkas, sedangkan pada faktor environment adalah ruang tunggu yang kurang nyaman terutama saat peak kunjungan pasien. Kekurang nyamanan dari faktor ruang yang panas, kurang luas dan tempat antrian pendaftaran sebagian masih diluar sehingga membuat beberapa pasien yang lanjut usia merasa kurang nyaman.

Dari semua faktor diatas kemudian disusun prioritas masalah. Dalam penyusunan prioritas masalah ini peneliti melakukan brainstorming dengan staf di unit rawat jalan. Didapatkan bahwa ada dua masalah utama dari optimalisasi di unit rawat jalan yaitu pertama pada masalah sumber daya manusia yang kurang terutama tenaga dokternya sehingga jadwal praktek di rawat jalan masih longgar. Kedua adalah masalah environment yang kurang nyaman terkait dengan ruang tunggu yang sudah 
tidak memadai. Sesuai dengan penelitian yang dilakukan oleh Aprilya (2013) yang menyatakan bahwa environment memberikan pengaruh pada kepuasan pasien (9). Penambahan tenaga dokter maupun jam praktek dokter merupakan salah satu solusi untuk mengotimalkan unit rawat jalan ini, tapi hal ini akan menuntut pemenuhan kebutuhan lainnya, misalnya tenaga asisten, sarana dan prasarana yang lebih memadai. Ketika digali lebih jauh ternyata permasalahan tentang tenaga dokter dan keluhan pasien tentang ruang tunggu yang tidak nyaman sudah disampaikan staf di unit rawat jalan kepada pihak manajemen tetapi belum ada tindak lanjut sampai saat ini.

Gambar 3. Diagram 5 why's

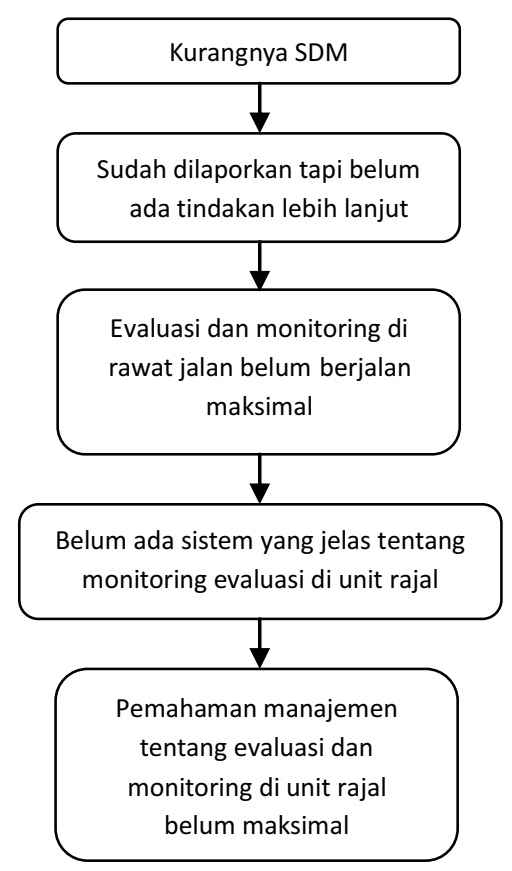

Melalui 5 why's ditarik kesimpulan bahwa sebenarnya yang mendasari dari semua permasalahan diatas adalah sistem monitoring dan evaluasi yang belum berjalan dengan maksimal. Evaluasi yang dilakukan pihak manajemen tentang optimalisasi unit rawat jalan belum mendalam sehingga dalam memutuskan kegiatan yang akan dilakukan untuk pengembangan atau tindakan lanjutan tidak berdasarkan hasil evaluasi yang tepat. Evaluasi dan monitoring sangat dibutuhkan dalam mengoptimalkan sebuah kegiatan. Kekurangan sumberdaya manusia yang telah diidentifikasi dan dilaporkan tidak dapat ditindaklanjuti secara sistematis karena lemahnya sistem evaluasi dan monitoring.

\section{DISKUSI}

Hasil penelitian menunjukkan utilitas ruang di poliklinik RS $X$ masih sangat kurang. Standar utilitas ruang dianggap baik bila mencapai angka $80 \%$. Salah satunya adalah utilisas ruang poli spesialis anak. Ruang poli anak hanya digunakan sebesar $22,4 \%$. Salah satu penyebabnya karena jadwal dokter spesialis anak yang praktek masih sangat rendah. Sedangkan penilaian untuk optimalisasi ruang adalah dengan membandingkan jumlah total jam praktek semua dokter spesialis anak dengan jumlah kunjungan pasien. Pada poli spesialis anak optimalisasi juga masih sangat rendah yaitu $5,75 \%$. Hal ini menggambarkan bahwa optimalisasi ruang juga masih rendah.

Untuk meningkatkan utilitas dan optimalisasi pada unit rawat jalan diperlukan peran manajemen. Terdapat beberapa masalah yang dihadapi dalam mengelola unit rawat jalan di RS X ini, misalnya masih banyak jam praktek yang masih kosong, jam praktek yang tidak merata, dokter spesialispurna waktu belum lengkap, adanya keluhan tentang keterlambatan dokter datang pada jam praktek yang telah ditentukan, adanya jeda waktu yang cukup panjang antara praktek dokter, dan masalah-masalah yang lain. Manajemen mempunyai peran yang sangat besar pada proses pelayanan di unit rawat jalan terutama klinik, antara lain adalah gaya kepemimpinan pelayanan di unit rawat jalan spesialis yang mampu memberikan pengaruh dan arahan terhadap fungsi dan tugas dokter spesialis untuk menjalankan pelayanan, pelaksanaan pengorganisasian di unit rawat jalan spesialis dalam memberikan pelayanan, kegiatan pengawasan pelayanan di unit rawat jalan spesialis dengan melakukan audit/evaluasi dan penilaian kinerja, kejelasan dan kesesuaian jasa dengan kinerja dokter spesialis, lingkungan kerja pelayanan di unit rawat jalan spesialis, dan kelengkapan sarana (10).

Upaya-upaya manajemen yang harus dilakukan dalam mengelola di unit rawat jalan spesialis terutama yang berkaitan dengan pengembangan sumber daya manusia, pemeliharaan dan pemenuhan sarana prasarana, dan pembuatan standar prosedur operasional (SPO) sudah dijalankan. Hal tersebut belum terlaksana dengan baik dikarenakan manajemen belum begitu memahami tentang monitoring dan evaluasi khususnya di unit rawat jalan.

Menurut Peraturan Pemerintah Nomor 39 Tahun 2006, disebutkan bahwa monitoring merupakan suatu kegiatan mengamati secara seksama suatu keadaan atau kondisi, termasuk juga perilaku atau kegiatan tertentu, dengan tujuan agar semua data masukan atau informasi yang diperoleh dari hasil pengamatan tersebut dapat menjadi landasan dalam mengambil keputusan tindakan selanjutnya yang diperlukan. Tindakan tersebut diperlukan seandainya hasil pengamatan menunjukkan adanya hal atau kondisi yang tidak sesuai dengan yang direncanakan semula. Tujuan monitoring adalah untuk mengamati dan mengetahui perkembangan dan kemajuan, identifikasi dan permasalahan serta antisipasinya maupun upaya pemecahannya. Definisi evaluasi menurut The Development Assistance Committee merupakan proses menentukan nilai atau pentingnya suatu kegiatan, kebijakan, atau program. Evaluasi merupakan sebuah penilaian yang seobjektif dan sesistematik mungkin terhadap sebuah intervensi yang direncanakan, sedang berlangsung atau pun yang telah diselesaikan (1). Evaluasi memerlukan hasil dari monitoring dan digunakan untuk kontribusi program. Monitoring bersifat spesifik program, sedangkan evaluasi tidak hanya dipengaruhi oleh program itu sendiri, melainkan variabel-variabel dari luar. Tujuan dari evaluasi adalah evaluasi efektifitas dan cost effectiveness.

Terdapat beberapa perbedaan antara monitoring dan evaluasi. Monitoring dilakukan terus menerus, dengan mengukur output dan proses, sering fokus pada input, kegiatan, kondisi/asumsi. Sumber informasi monitoring 
berdasarkan laporan, survei kecil, dan dokumen internal. Monitoring biasanya berfungsi sebagai pemberi feed back kepada pelaksana dari manajer. Disisi lain evaluasi dilakukan setelah akhir program dengan mengukur adalah dampak jangka panjang dan kelangsungan program. Sumber informasi didapatkan dari dokumen internal dan eksternal, assesmen dampak dan riset evaluasi. Hasil dari evaluasi biasanya digunakan sebagai koreksi mayor program, perubahan kebijakan, strategi masa mendatang, termasuk penghentian program.

Selain monitoring dan evaluasi program juga perlu dilakukan evaluasi kinerja. Penilaian kinerja dilakukan dengan tujuan mengevaluasi kinerja untuk meningkatkan kemampuan individu, kelompok dan seluruh organisasi. Salah satu bentuk evaluasi kinerja adalah dengan memberikan feedback secara berkelanjutan yang terbukti efektif untuk meningkatkan komitmen kinerja (12). Evaluasi kinerja merupakan bagian dari fungsi manajemen yang penting yaitu evaluasi dan pengawasan (evaluating and controlling). Dengan evaluasi kinerja maka bisa ditunjukkan posisi dan tingkat pencapaian suatu perusahaan terutama untuk mengetahui bila terjadi keterlambatan atau penyimpangan supaya segera diperbaiki, sehingga sasaran atau tujuan akhir dapat

\section{DAFTAR PUSTAKA}

1. Notoatmodjo S. Ilmu Kesehatan Masyarakat: PrinsipPrinsip Dasar. Jakarta: PT Rinneka Cipta; 2003.

2. Hariyanti RE. Analisis Strategi Pemasaran Pelayanan Skin Medical Center di Rumah Sakit PKU Muhammadiyah Yogyakarta. Jurnal Kesehatan Masyarakat. 2010; 4: 76-82.

3. Philip K dan Lane KK. Manajemen Pemasaran. Jakarta: Erlangga; 2009.

4. Hafizurrachman. Kepuasan Pasien dan Kunjungan Rumah Sakit. Jurnal Kesehatan Masyarakat Nasional. 2009; 4(1): 10-17.

5. Singh $\mathrm{H}$. The Importance of Customer Satisfaction in Relation to Customer Loyalty and Retention. [Working Paper]. Asia Pacific University College of Technology \& Innovation Technology Park, Malaysia. 2006.

6. Aga NA, Hendrartini J, dan Margo V. Perbandingan Tingkat Kepuasan Peserta Askes Wajib dan Sukarela terhadap Mutu Pelayanan Kesehatan Tingkat I. Jurnal Manajemen Pelayanan Kesehatan. 2005; 8(4): 183-190.

7. Suharmiati dan Didik B. Analisis Faktor-faktor yang Mempengaruhi Tingkat Kepuasan Responden Pengguna Rawat Jalan Rumah Sakit Pemerintah di Indonesia. Buletin Penelitian Sistem Kesehatan. 2007; 10(2): 123-130. tercapai. Sejalan dengan penelitian terdahulu oleh Trisabekti yang menyatakan bahwa evaluasi kerja mempunyai pengaruh yang signifikan terhadap kinerja karyawan (13).

Berdasarkan hasil penelitian, ditemukan bahwa terdapat gap antara hasil dari utilitas ruang dan optimalisasi dokter di unit rawat jalan RS X. Faktor-faktor utama penyebab timbulnya gap yang mengakibatkan kurang optimalnya unit rawat jalan adalah kapasitas sumber daya manusia yang kurang dan lingkungan yang kurang nyaman. Kekurangan tersebut terjadi karena sumberdaya manusia yang ada belum melakukan sistem monitoring dan evaluasi secara maksimal. Solusi yang diusulkan adalah dengan memberikan pelatihan kepada manajemen tentang metode evaluasi dan monitoring. Pelatihan berfungsi untuk meningkatkan pengetahuan, ketrampilan dan sikap. Pelatihan merupakan sebuah proses yang mengajarkan pengetahuan dan keahlian tertentu serta sikap agar karyawan semakin terampil dan mampu melaksanakan tanggung jawabnya dengan semakin baik dan sesuai dengan standar. Hal ini sesuai dengan pernyataan Lumbanraja bahwa dengan pemberian pelatihan berpengaruh positif terhadap prestasi kerja karyawan (14).

8. Trisnantoro L. Memahami Ilmu Ekonomi dalam Manajemen Rumah Sakit. Yogyakarta: Gajah Mada University Press; 2009.

9. Aprilya V. Pengaruh Dimensi Kualitas Pelayanan tehadap Kepuasan Pelanggan J.Co Cabang Padang. Jurnal Manajemen. 2013; 2(1): 9.

10. Kriswidiati K, Sudiro S, dan Mawarni A. Analisis Faktorfaktor Manajemen Pelayanan Rawat Jalan yang Mendukung Utilisasi Klinik Spesialis di Rumah Sakit Panti Wilasa Citarum Semarang. [Tesis]. Universitas Diponegoro, Semarang. 2014.

11. The Development Assistance Committee. Glossary of Key Terms in Evaluation and Results Based Management. Paris: OECD Publication; 2010.

12. Syarifah D. Feedback yang Berkelanjutan (Continuous Feedback) untuk Mendukung Penilaian Kinerja Efektif. INSAN. 2012; 14(2): 120-126.

13. Bambang T. Pengaruh Evaluasi Kerja terhadap Kinerja Karyawan (Studi Empirik di Bank Pengkreditan Rakyat Syariah Margirizki Yogyakarta). [Skripsi]. UIN Sunan Kalijaga, Yogyakarta. 2014

14. Lumbanraja P. Pengaruh Pelatihan dan Karakteristik Pekerjaan terhadap Prestasi Kerja Perawat di Badan Pelayanan Kesehatan Rumah Sakit Umum Daerah Langsa. Jurnal Manajemen dan Kewirausahaan. 2010; 12(2): 142-155. 